\title{
Sob o signo da dualidade: Joseph de Maistre e a Casa da Sabóia na 'Era da Revolução Democrática'
}

Under the Sign of Duality: Joseph de Maistre and the House of Savoy in the "Age of Democratic Revolution"

\section{José Miguel Nanni Soares \\ Doutorando em História Social pela Universidade de São Paulo (FFLCH/ USP-São Paulo/Brasil) e bolsista da Fundação de Amparo à Pesquisa do Estado de São Paulo (FAPESP). e-mail:miguelnanni@uol.com.br}

\author{
Resumo \\ Este artigo pretende explorar o impacto exercido tanto pela Revolução \\ Francesa como pelas invasões napoleônicas sobre o reino do Piemonte-Sardenha \\ e, sobretudo, as reações de um de seus mais célebres súditos, o \\ contra-revolucionário saboiano Joseph de Maistre (1753-1821) \\ às mesmas, seja na condição de publicista, seja nas atribuições de \\ estadista (embaixador sardo na Rússia, entre 1803-1817). À guisa do \\ sesquicentenário da unificação italiana celebrado em 2011, buscamos \\ reconstituir, por meio do testemunho intelectual de Maistre, alguns dos \\ muitos e intricados mosaicos que compuseram o processo de unificação \\ daquela península, destacando os dilemas identitários suscitados pelos \\ desdobramentos revolucionários nos territórios da Casa da Sabóia, \\ bem como a importância (certamente indireta e involuntária, mas \\ não desprezível), para o futuro desfecho deste paradoxal processo de \\ unificação, do contra-revolucionário saboiano.
}

\begin{abstract}
This article aims to explore the impact exerted by both the French Revolution and the Napoleonic invasions on the kingdom of Piedmont-Sardinia, and especially the reactions of his famous counter-revolutionary Savoyard subject, the count Joseph de Maistre (1753-1821) to them - first as a publicist, latter as a statesman (Sardinian ambassador in Russia between 1803-1817). In the manner of the sesquicentennial of the Italian unification celebrated in 2011, we seek to reconstruct, through the intellectual testimony of Maistre, some pieces of the intricate mosaic that made up the unification process of that peninsula, highlighting the identitarian dilemmas posed by the revolutionary developments in the territories of the House of Savoy, as well as the importance (certainly indirect and unintended, but not negligible), for the future outcome of this paradoxical process of unification, of the counter-revolutionary Savoyard.
\end{abstract}

Palavras-chave

Revolução Francesa, Historiografia, conservadorismo, Unificação Italiana, Maistre

Keywords

French Revolution, Historiography, conservatism, Italian Unification, Maistre 
MAISTRE, Joseph de. Lettre A M. le Marquis D'Azeglio, 21/02/1821. In: Oeuvres complètes de Joseph de Maistre (De agora em diante, apenas OC). Lyon: Vitte et Perussel, vol.XIV, 1886. p.258259. Esta e as demais traduções são de inteira responsabilidade do autor.

2

PALMER, Robert R. The Age of the Democratic Revolution:The Challenge. Princeton: Princeton Univ. Press, 1959.

3

ELLIOT, John. H. A Europa Dividida:1559-1598 (1968). Trad. de Conceição Jardim e Eduardo Nogueira. Lisboa: Editorial Presença, 1985. p.55-57.

4

Conforme célebre e nada diplomática "boutade" proferida pelo embaixador francês, Charles de Brosses, nos anos 1740: a Itália era como uma "alcachofra" que a Casa de Sabóia devorava "folha a folha. In: NICOLAS, Jean. La Savoie au XVIII siècle: noblesse et bourgeoisie (1978). Montmélian: La Fontaine de Siloé, 2003. p.626-627.
A cinco dias de seu falecimento, o contra-revolucionário saboiano Joseph de Maistre (1753-1821) fez a seguinte pergunta: "somos ou não [somos] italianos? Ao passo que em Florença somos chamados de nação anfíbia, ou enquanto por aqui dissermos 'chegou o correio da Itália?', viverei sempre com a mesma dúvida"'.

No ano em que a Itália completa o sesquicentenário de sua independência e unificação, gostariamos de destacar algumas das circunstâncias históricas especificas responsáveis pelo paradoxal desfecho do processo de unificação da península itálica, cuja liderança coube a uma monarquia absolutista provinciana e de origem estrangeira (partindo da periferia para o centro, portanto). Paralelamente, buscaremos reconstituir a maneira pela qual, na era da revolução democrática ${ }^{2}$, os conceitos de nacionalidade e patriotismo articulavam-se no pensamento do saboiano Joseph de Maistre.

Nosso relato tem início na segunda metade do século $\mathrm{XV}$, a qual coincide com o fim da 'era de ouro' do Renascimento italiano, quando as ricas cidades do centro e do norte da península italiana foram incapazes de sustentar suas liberdades frente aos novos e poderosos inimigos, as monarquias absolutistas estrangeiras (mormente França e Espanha).

Mais ou menos no mesmo período em que as repúblicas perdiam suas liberdades (como Florença) e/ou eram obrigadas a se retrair numa política oligárquica conservadora para sobreviver (Gênova, Luca e Veneza), o ducado da Sabóia tornava-se uma exceção entre as monarquias europeias, as quais ainda enfrentavam suas nobrezas recalcitrantes no processo de centralização. Apesar do acréscimo do poder monárquico no seu conjunto exércitos (permanentes) mais fortes, maiores facilidades financeiras, uma organização administrativa mais eficaz e um controle mais estreito sobre a igreja nacional -, importa salientar, como fez J. H. Elliott, que "o monarca do século dezesseis era, apesar de tudo, pouco mais do que um primus inter pares." Contudo, para Manuel Felisberto da Sabóia, "testa de ferro" de Filipe II e responsável pela vitória do exército espanhol sobre as tropas francesas de Henrique II na batalha de Saint-Quentin (1557), em Flandres, as condições eram diferentes: herdeiro de um Estado destruído e "estando as classes dirigentes desintegradas e desmoralizadas após meio século de ocupação estrangeira, não havia alternativa para uma política radical de reconstrução do Estado, pessoalmente dirigida por um duque absolutista. Mas o Piemonte era uma exceção"3.

0 tratado de Cateau-Cambrésis (responsável pela transferência da capital do ducado de Chambéry, na Sabóia, para Turim), de 1559, e as fracassadas políticas expansionistas à oeste do seu sucessor, Carlo Emanuele I, orientaram definitivamente a política expansionista dos duques para a península itálica, a despeito das origens francesas (ou melhor, borgonhesas) do ducado. No final do século XVII e início do XVIII - isto é, após nova invasão francesa de 1690 sob a égide do "rei sol" -, o liame orgânico que ligava o Estado piemontês com seus súditos francófilos saboianos arriscava ser rompido, como testemunharam os comandantes e oficiais de ocupação franceses entre 1690 e 1703, recebidos e aclamados em Chambéry como "libertadores". Como todas as iniciativas dos duques dirigiam-se para os domínios da Itália, os observadores diplomáticos estrangeiros descreviam a Itália como uma alcachofra que os duques da Sabóia devoravam folha por folha. ${ }^{4}$

Como destacou Perry Anderson, "o avanço rumo ao absolutismo centralizado foi decisivamente concluído por Vittorio Amadeo II, no início do século XVIII. Uma habilidosa mudança de lados na Guerra da Sucessão 
5

ANDERSON, Perry. Linhagens do Estado Absolutista (1974). Trad. de João R. Martins Filho. São Paulo: Brasiliense, 2004, $3^{a}$ edição. p.171-172.

6 NICOLAS, Jean. Op. Cit., p.596.

7 PORCHNEV, Boris. Les soulèvements populaires en France au XVII siècle (1963). Paris: Flammarion, 1972. p.399.

8

WOOLF, Stuart. A History of Italy 1700-1860. The Social Constraints of Political Change (1979). New York: Routledge, 1991. p.68.

9

GRAMSCl, Antonio. // Risorgimento (1975). Torino: Riuniti, 1991. p.132.

10

Isto é, levando-se em conta o conceito de a "grande revolução de 1789-1848" consagrado pelo historiador Eric J. Hobsbawm, vale dizer, da "revolução dupla": na economia, triunfo da indústria capitalista; na política, ascensão da classe média e triunfo do conceito burguês de liberdade. Aplicado à situação histórica da península itálica posterior à existência de Maistre, este conceito permite destacar ainda mais a excepcionalidade politica piemontesa (cuja estrutura social aristocrática, decisiva para a unificação, logrou sobreviver, não sem concessões, à ascensão das classes médias, sobretudo após 1848) no interior da península, cujo papel no processo de unificação italiana só pode ser comparável - o que não significa dizer que foi idêntico - ao que a Prússia desempenhou no processo de unificação da Alemanha (em linhas gerais, liderado também por um Estado periférico, fortemente centralizado e socialmente marcado pelo controle político da aristocracia). In. HOBSBAWM, Eric J. A Era das Revoluções, 1789-1848 (1962). Trad. de Maria Tereza Lopes Teixeira e Marcos Penchel. São Paulo: Paz e Terra, 2005, 19a edição. p.16.
Espanhola, da França para a Áustria, garantiu aos duques da Sabóia, através do Tratado de Utrecht (1713), o condado de Montserrat e a ilha da Sardenha, e o reconhecimento europeu de sua elevação de ducado para monarquia, que passou a se chamar reino do Piemonte-Sardenha. Sinuoso na guerra, Vittorio Amadeo usou a paz que se seguiu para instalar uma severa administração copiada à de Colbert, onde não faltavam sequer um Conselho e um sistema de intendants. Ele então desenfeudou amplas faixas de terras da nobreza com o recurso a um novo registro cadastral, aumentando desse modo as receitas fiscais, já que os domínios alodiais estavam sujeitos a impostos; construiu um amplo aparelho diplomático e militar ao qual se integrou a aristocracia, extinguiu as imunidades do clero e subordinou a Igreja"s.

Não obstante o enquadramento e cerceamento da nobreza feudal, a autoimagem que a monarquia fazia de si persistiu sendo feudal. "Com efeito, situada no cume de uma hierarquia única, a monarquia piemontesasarda coroava uma estrutura nobiliárquica centralizada, ampliada a partir de então pelas elites plebeias cujos membros eram absorvidos um a um e transformados em células de execução do sistema administrativo e político. Como na Prússia de Frederico, no Piemonte o serviço civil desenvolvia-se 'segundo uma concepção feudal da função pública' e num espírito de completa lealdade em relação ao soberano"'.

Especialistas como Jean Nicolas e Stuart Woolf sublinharam o fato de que a monarquia savoiarda, à diferença da francesa - onde, na bela definição de Boris Porchnev, a burguesia fazia um jogo de "cobra-cega" com a monarquia ${ }^{7}$-, lograva amortecer os conflitos entre as diferentes ordens ao acomodá-las em seu grande regaço burocrático, num processo que culminava na formação de uma ética comum ("funcionalismo") entre os membros daquela elite.

Segundo Stuart Woolf, essas reformas de caráter "prussiano" produziram um duplo efeito: por um lado, fizeram do reino subalpino "o mais eficientemente organizado, burocrático-militarista Estado da Itália, com uma genuína tradição de lealdade para com a dinastia entre as classes dominantes", por outro (e, curiosamente, devido ao êxito das mesmas), impermeabilizaram o Estado para o surgimento de uma classe intelectual independente e crítica. ${ }^{8}$

Este último aspecto levou Antonio Gramsci a comparar o papel desempenhado pelo reino do Piemonte-Sardenha na unificação italiana ao de um moderno "partido", sem o qual não se compreende o caráter "passivo" da Revolução/Unificação italiana. ${ }^{9}$ Dadas as condições da península itálica após a Revolução Francesa de 1789 e o período napoleônico (período marcado pela pulverização das reminiscências republicanas medievais e dos pequenos ducados), só a monarquia saboiana dispunha da "base lógica" para a unificação, pois só ela fora capaz de desenvolver na península um verdadeiro absolutismo nativo claramente alicerçado numa nobreza feudal, numa formação social dominada pela aristocracia. 0 fato da Casa da Sabóia, na era das revoluções burguesas ${ }^{10}$, dispor de um exército e de uma diplomacia independentes e bem consolidadas, não seria de menor relevância para seu futuro papel histórico de condutor da unificação da península itálica.

A história do conde saboiano Joseph de Maistre após a Revolução de 1789 mais do que confirma esta excepcionalidade piemontesa. Não seria incorreto dizer que Maistre nasceu e viveu sob o signo da dualidade: primeiramente, uma dualidade cultural e social, e, por outro lado, uma dualidade geopolítica. 
11

Dualidade esta já abordada, dentre outros, por LEBRUN, Richard. Joseph de Maistre: an intellectual militant. Quebec: McGill-Queen's University Press, 1988; e PRANCHĖRE, Jean-Yves. L'autorité contre les Lumières: la philosophie de Joseph de Maistre. Genève: DROZ, 2004.

12

NICOLAS, Jean. Op. Cit., p.613.

13

MAISTRE. Joseph de. Arquivos da Sabóia, B 1167, conclusões de 28 de julho de 1784.
Maistre nasceu, se formou e ultrapassou o "mezzo del cammin" de sua vida (39 anos) em Chambéry, quando foi atingido em cheio pela invasão das tropas revolucionárias francesas na Sabóia (setembro de 1792).

Com efeito, por sua origem e meio social, Maistre era burguês e nobre a um só tempo: membro do senado local e, portanto, pertencente à nobreza de toga saboiana, a nobilitação de sua família foi a coroação de um longo esforço de ascensão social de uma casa de comerciantes de tecidos da província de Nice. Paradoxalmente, um olhar mais atento sobre a biografia de Maistre mostrará que a chave para a explicação do contra-revolucionário e fiel súdito do rei do Piemonte-Sardenha está justamente nesta origem "burguesa' do mesmo, e não o contrário."

Antes que a Revolução o transformasse num dos expoentes mais veementes do pensamento conservador em língua francesa, Maistre exercia a função de Senador da Província da Sabóia, cargo que desempenhou de 1788 a 1792.

A respeito do Senado da Sabóia, devido às reformas absolutistas do começo do século XVIII (as quais tiveram a estreita colaboração de seu pai), o mesmo teve - a exemplo dos parlements franceses no século precedente - sua competência restringida quase que exclusivamente aos assuntos jurídicos. Entre 1717 e 1731, o rei Vittorio Amadeo II reorganizou o ConseIho de Estado em Turim e reforçou a autoridade monárquica nas províncias, por meio do envio de intendentes.

Essas medidas visavam disciplinar a recalcitrante e orgulhosa nobreza saboiana, cujo histórico de atritos com a administração central piemontesa remontava a meados do século XVI: apesar de suas origens político-culturais borgonhesas, havia muito que os duques da Sabóia orientavam sua política cada vez mais para a conquista de territórios setentrionais da península italiana, especialmente após o tratado de Cateau-Cambrésis (1559) entre França e Espanha, política esta que tendia naturalmente a privilegiar a nobreza piemontesa em detrimento da saboiana.

Assim, pode parecer à primeira vista estranho o fato de os saboianos Maistre (tanto o pai, François-Xavier, um dos formuladores das reformas absolutistas dos anos 1730; quanto o filho, Joseph) estarem entre os funcionários mais abnegados na execução desta política centralizadora piemontesa naquele senado provincial. Contudo esse estranhamento é disperso assim que analisamos a trajetória familiar dos senadores.

Sem nunca ter possuído um feudo, os rendimentos da família de Maistre provinham em sua maior parte (cerca de 60\%) dos salários de seus cargos, e não das exações sobre os camponeses em seus domínios (que representava pelo menos $2 / 3$ dos ganhos dos feudatários). Por outro lado, detinham o signo distintivo da nobreza, qual seja, o privilégio ou isenção de tributos, mormente a talha real. ${ }^{12}$

Isto explica o fato de que, apesar de cooptados pela nobreza hereditária, os Maistre sempre manifestaram oposição aos anacrônicos direitos feudais que ainda pesavam sobre as terras, pelo que se depreende pela conclusão dada pelo filho Joseph a respeito de um julgamento de 1784 , em que um pleiteante reclamava seus direitos feudais:

No lugar das Luzes, da Ordem, da Tranqüilidade que reinam em nossos dias, é preciso imaginar os distúrbios, a anarquia, as devastações da Idade Média; é preciso lembrar da feroz independência dos nobres, a influência ilimitada do clero, a nulidade do povo e a ignorância de uns e de outros. ${ }^{13}$ 
14

Sobre a história do conceito de "direito natural" na cultura política francesa do século XVIII, da Ilustração até o momento em que o mesmo se torna hegemônico como argumento político, vale dizer, nos quadros de radicalização e dissensão republicana durante o julgamento de Luis XVI, leia-se EDELSTEIN, Dan. The Terror of Natural Right: Republicanism, the Cult of Nature, and the French Revolution. Chicago: University of Chicago Press, 2009.
Quando a Assembléia Nacional francesa, em sua última reunião antes de ceder lugar à Convenção Nacional (em 20 de set. de 1792), votou pela guerra contra o reino piemontês (pelo fato do mesmo acolher os émigrés franceses), todos na Sabóia sabiam que a invasão era uma questão de tempo. Nesta mesma data, Maistre e sua familia já haviam recolhido o máximo que podiam e partido para os Alpes italianos.

Após a rápida e fácil invasão liderada pelo general Montesquiou no dia 22 de setembro, os franceses organizaram eleições para deputados em todos os distritos da Sabóia, dando origem à Assembléia Nacional dos Allobroges. 0 primeiro ato desta assembléia, que se reuniu em 21 de outubro de 1792, foi enviar à Convenção Nacional de Paris uma petição unânime, requerendo a incorporação da província à França. 0 que pretendiam os franceses com aquela invasão e, para além do argumento sobre os emigrados, como a justificavam?

Com base na tese republicano-natural ${ }^{14}$, a qual se tornaria hegemônica a partir do processo de Luís XVI, a França revolucionária enviava duas mensagens aos saboianos e aos soberanos europeus: 1. Pelo direito natural, válido acima de todas as leis e códigos, os saboianos eram os legítimos soberanos de sua pátria (justificando-se, assim, a quebra do vínculo político com o reino do Piemonte); 2 . A nação francesa generosamente convidava os seus vizinhos, os habitantes da Sabóia e com quem possuiam um longo histórico de convivência, para integrarem, mediante decisão livre e soberana de seus membros, a República Francesa una e individivel, a fim de melhor assegurarem seu direito natural reconquistado contra os monarcas, especialmente o soberano do Piemonte-Sardenha.

Diante disso, a Assembléia foi dissolvida e o poder entregue a um comitê executivo, cujo primeiro ato foi o de ordenar um inventário das propriedades da Igreja e ameaçar com o confisco todos os emigrados que não retornassem até a data de $1^{\circ}$ de janeiro de 1793. Em 18 de novembro de 1792, a Convenção Nacional promulgou um decreto que unia a Sabóia à França, passando-se a chamar Departamento de Mont-Blanc.

Neste ínterim, a maior parte dos cidadãos saboianos que, a exemplo de Maistre, preferiram conservar sua lealdade dinástica, emigraram para a capital do reino (Turim), na esperança de que seriam tão bem ou melhor recebidos do que os emigrados franceses. Para consternação dos saboianos, o tratamento dispensado a eles pela corte e pela população piemontesa em geral foi a mais hostil possivel. Diante da falta de ocupação, da má recepção e da ameaça da perda dos bens, não foram poucos os refugiados saboianos que, como Maistre, optaram por abandonar Turim e se apresentar, com a autorização do rei, às autoridades da Sabóia francesa/revolucionária.

Com respeito a Maistre, é preciso dizer que em sua breve estadia de pouco mais de três meses na Chambéry 'francesa', o mesmo não empreendeu nenhum esforço para se adaptar ao 'novus ordo seclorum'. Pelo contrário, antes de emigrar definitivamente de sua terra natal, redigiu anonimamente (fev. 1793) um curioso relatório dirigido aos deputados franceses ("Súplica de alguns pais de militares saboianos à Convenção Nacional dos Franceses"), no qual não apenas compreendia a punição imposta pela Convenção aos émigrés franceses, como questionava veementemente a identificação, pela Convenção Nacional Francesa, dos emigrados saboianos com aqueles (ou seja, não havia justificativa legal para enquadrá-los na lei contra os émigrés). Pois, segundo Maistre, enquanto a emigração francesa foi um abandono e traição à realeza - na medida em que minava sua autoridade junto à opinião 
MAISTRE, Joseph de. Adresse de quelques parents des militaires savoisiens à la Convention Nationale des Français (1793). In: OC, Vol.VII, p.72

16

Ibidem, p.55 pública e alimentava o jacobinismo -, a saboiana foi justamente o oposto: representou uma demonstração de patriotismo para com seu soberano legítimo e à 'pátria universal', o reino do Piemonte-Sardenha. ${ }^{15}$

Portanto, foi em reação à anexação da Sabóia à França e ao enquadramento da aristocracia saboiana na lei de emigração francesa que Maistre redigiu o panfleto, demonstrando, pela lógica interna dos próprios revolucionários franceses, que os saboianos apenas cumpriram seus deveres patriótico-constitucionais e obedeciam à lei de sua pátria universal ao emigrarem, a qual prescrevia, como primeira lei do reino, a obediência ao soberano da Casa da Sabóia. Ademais, provocava Maistre, a província da Sabóia não integrava o território 'uno e indivisivel' do reino do Piemonte, condição esta reconhecida e legitimada pelo direito internacional havia mais de oito séculos?

\footnotetext{
A pátria de um homem é o país inteiro submetido à dominação de seu soberano, qualquer que seja o mesmo. As subdivisões deste país podem ainda formar, num sentido muito estrito, pátrias particulares, mas cujos interesses - subordinados ao bem geral - não podem perturbar a pátria universal, nem prejudicar o exercício da soberania: do contrário, não haverá mais governo... 0 que significa, pois, esta afetação com a qual alguns se obstinam a ver nesta imperceptível Sabóia um pais isolado, autônomo e, por assim dizer, uma quinta parte do globo? Como se a Sabóia fosse outra coisa senão uma província dos Estados de S. M. o Rei da Sardenha! Como se o governo não tivesse sido sempre perfeitamente uno e indivisível! ${ }^{16}$
}

Este parágrafo sintetiza exemplarmente a dualidade cultural e geopolítica na qual se inseria o contra-revolucionário saboiano. Maistre não ignora as dificuldades postas pela Revolução Francesa e seu momento republicano-democrático às monarquias européias, especialmente ao reino do Piemonte, cuja estratégica e histórica província, não só era francófila, como se tornara o primeiro alvo dos deputados republicanos franceses, que reivindicavam a anexação daqueles territórios alpinos sob o pretexto das fronteiras naturais.

À diferença de boa parte de seus amigos saboianos, Maistre preferiu perder a maior parte dos bens a trair sua lealdade dinástica e religiosa. Razão pela qual decidiu emigrar novamente, desta vez para a cidade suiça de Lausanne, donde redige, logo após sua chegada (em 15 de abril de 1793) e graças ao incentivo do contra-revolucionário suiço Jaques Mallet du Pan (1749-1800), as quatro primeiras Cartas de um realista saboiano a seus compatriotas, panfletos publicados entre maio e agosto daquele ano.

As Cartas saboianas tinham o triplo objetivo de convencer as autoridades piemontesas a reconquistar a antiga província, galvanizar os habitantes locais a se juntarem às tropas austro-sardas, cuja invasão estava programada para o verão de 1793 e, por fim (e de maneira implícita), convencer o governo de Turim a adotar medidas mais 'liberais' como a maneira mais eficaz de se preservar do contágio Revolucionário (anistiando os saboianos republicanos pró-franceses e substituindo a velha política, caracterizada por ele como a 'batônecratie' ou 'turinismo', por uma atuação mais efetiva junto à opinião pública).

0 aspecto mais curioso desta peça de propaganda realista designada para circular na Sabóia e composta sem a autorização do governo (que enxergava suspeitas jacobinas em qualquer iniciativa intelectual), era a defesa da monarquia sarda (vale dizer, Casa da Sabóia) em termos utilitários e racionais, e não mediante os apelos tradicionais à honra e ao dever. No 
17

MAISTRE, Joseph de. Apud. DARCEL, Jean-Louis (org). Présentation de Écrits sur la Révolution. Paris: PUF, 1989. p.21.
MAISTRE, Joseph de. Lettres d'un royaliste savoisien a ses compatriotes (1793). In: OC, Vol. VII, p.36.

19

Quanto a Michelet, o fato de aludir às Considerações em sua Histoire de la Révolution française, apenas confirma a excentricidade deste panfleto contra-revolucionário, que, apesar de representar uma refutação radical da Revolução Francesa, ofereceu ao professor republicano argumentos contundentes que serviram para reforçar suas críticas aos resquícios feudais e à aristocracia do antigo regime: "Eram uma classe de homens muito heterogêneos, mas em geral fracos e fisicamente decadentes, levianos, sensuais e sensiveis..." É o que reconhece o sr. de Maistre em suas Considerações sobre a França." In: MICHELET, Jules. Histoire de la Révolution française. Livro II, cap. III. Mais adiante, certo é que Michelet se remetia às Considerações quando dizia: "Os emigrados arriscavam vencer, assassinar a pátria, para sua desonra eterna. Ter-Ihes-ia dito M. de Maistre: 'Oh, infelizes, felicitai-vos por terem sido derrotados pela Convenção!... Teríeis, pois, querido uma França desmembrada e destruida?" In: MICHELET, Jules. Histoire de la Révolution française. Livro XIII, cap.I.

20

MAISTRE, Joseph de. Lettres d'un royaliste savoisien a ses compatriotes, 0p. Cit, p.83-84.
Prefácio à $2^{a}$ edição (1793), em que o autor reagrupou as quatro primeiras cartas publicadas separadamente, Maistre explicitou suas intenções. Nele testemunhamos a dificuldade que a Revolução Francesa (e seu conceito democrático de patriotismo) impôs a todos os regimes monárquicos, dificuldades estas que se tornavam ainda mais agudas naquela província de matriz cultural francesa sob o domínio de um Estado absolutista 'italiano':

Outrora, a autoridade podia dispensar a ciência, e a obediência, a reflexão: hoje, produziu-se uma grande transformação nos espíritos, e essa transformação é obra de uma nação extraordinária, infelizmente muito influente (...). Nossa situação... é bem melhor do que a vivida pelos franceses: a revolução é um fruto estranho trazido pela França e que ainda não está, a bem dizer, aclimatado entre nós (...). É preciso trabalhar sobre a opinião; desmistificar as teorias metafísicas aos povos..., ensinar-lhes a perceber as vantagens daquilo que possuem; mostrar-Ihes o perigo de buscar um melhor imaginário sem calcular os infortúnios com os quais pagará pelo mesmo. ${ }^{17}$

Nas duas primeiras Cartas, Maistre habilmente denuncia as práticas revolucionárias em nome dos mesmos princípios que as animaram: em nome da Liberdade, da Igualdade e dos Direitos do Homem, violam-se as liberdades, as consciências, e a justiça, resultando naquilo que Maistre designaria como "guerra civil do gênero humano", o solapamento do Estado de Direito que ele, bem ou mal, identificava com a monarquia absolutista piemontesa-sarda. Mas o crime revolucionário por excelência, dirá no "Prefácio" da primeira carta, não era tanto o Terror quanto o desbaratamento simbólico da autoridade política. Numa passagem em que demonstra o pleno domínio da escritura polêmica e dos recursos de linguagem disponíveis a um panfletário, compara os revolucionários franceses a uma criança que estragou o próprio brinquedo enquanto tentava desvendar o mecanismo oculto de seu funcionamento:

No momento em que se oferece a uma criança um desses brinquedos que executam, por meio de mecanismos internos, movimentos inexplicáveis a ela, a mesma, após ter se divertido por algum tempo, quebra-o, para vê-los de fora. É assim que os franceses trataram seu governo. Quiseram ver de fora: expuseram os princípios políticos, abriram os olhos da multidão sobre objetos a respeito dos quais jamais suspeitara examinar, sem refletir que existem coisas que se destroem ao mostrá-las. ${ }^{18}$

Isto não o impedia de reconhecer o 'outro' lado da moeda (um lado crítico de Maistre tão bem observado e explorado por ninguém menos que o historiador republicano Jules Michelet em sua monumental História da Revolução Francesa, 1847-1853'19), a saber, que se o contágio dos 'falsos' princípios revolucionários era demasiado rápido, isto se devia à fraqueza geral do corpo político do Antigo Regime (razão pela qual, para seu desespero, soube que o governo de Turim confiscara todos os exemplares de seus panfletos, sob a suspeição de jacobinismo!):

Todavia, é preciso ter a coragem de confessá-lo com a mesma franqueza [que] na época memorável em que a França começa a se agitar, todos os governos da Europa haviam envelhecido, e esta decrepitude era conhecida apenas por aqueles que dela queriam tirar proveito na execução de seus projetos funestos. Milhares de abusos acumulados minavam estes governos, e, sobretudo o da França decaía em corrupção. ${ }^{20}$

Chama a atenção o fato de as Cartas lançarem mão da lógica interna do discurso revolucionário francês, ao defenderem que a 'massa da nação' 
saboiana (isto é os camponeses) era contrária à anexação francesa, a qual só foi possível graças à colaboração de uma minoria (a elite local) com os jacobinos franceses: "As vozes de uma condenável minoria levaram a melhor sobre os receios e a honra do resto da nação. Esta minoria queria a conquista e a revolução, e tivemos ambas. Agora podeis comparar e julgar"21. Ou seja, considerada a lógica do princípio rousseauista vigente (não sem contradições, é bem verdade) na França revolucionária, os adesistas saboianos, e não os emigrados locais, é que afrontavam a 'vontade geral' da nação saboiana.

Na perspectiva maistreana (alicerçada numa leitura liberal-aristocrática de Montesquieu), o exemplo oferecido pela Assembléia dos Deputados do Allobroges expôs risco do assembleísmo ou centralismo democrático, por detrás da atuação jacobina, para o sistema representativo:

Numa palavra, se excetuarmos um pequeno número de facciosos que ousaram se proclamar 'a Nação', temos que uma parte da Assembléia não escutou nada, a outra não compreendeu nada, e uma terceira não disse nada. Eis a história de vossa Assembléia popular e, talvez, de todas as outras. ${ }^{22}$

Farsa ou não, o fato é que o proselitismo da Revolução Francesa atuou como um poderoso solvente na esgarçada estrutura identitária das monarquias européias, e isto era ainda mais válido para o reino do Piemonte. A terceira Carta expressa bem a dificuldade do contra-revolucionário em exortar os sentimentos patrióticos dos saboianos a favor de uma monarquia que, desde o século XVI, definia-se cada vez mais como 'italiana', cujo absolutismo (tardio, consolidado em meados do século XVIII) coincidiu com o zênite dos movimentos reformistas nos países que haviam consolidado seu absolutismo havia tempos: "Não há nada mais importante para vós do que vos identificar com o Piemonte, e de acostumar-vos a observá-lo como a porção mais considerável de nossa pátria comum"23.

Ou seja, para Maistre, o amor pela pátria era consubstancial ao amor, ou melhor, respeito pelo soberano; de modo que a Sabóia era uma pátria menor inserida na grande pátria, o reino do Piemonte-Sardenha.

Para surpresa universal, todos os esforços militares contra a república revolucionária francesa redundaram em fracasso. Diante disto, estava cada vez mais claro para Maistre que a Revolução não poderia ser derrotada pela iniciativa dos exércitos coligados (os quais, pelo contrário, galvanizavam os sans-culottes parisienses e os camponeses em apoio à política terrorista dos jacobinos, pelo menos até que a ameaça estrangeira estivesse posta): para derrotá-la, era preciso 'destronar' os jacobinos da opinião pública e, para tanto, os ataques externos e ameaças deveriam cessar o quanto antes, sobretudo as ameaças de fragmentação da França que partiam da Prússia e da Áustria.

As Considerações sobre a França, panfleto responsável pela reputação literária e política de Maistre, publicado em abril de 1797, agravou a situação do súdito saboiano junto às autoridades de Turim, que passaram a designá-lo pejorativamente como 'Il Francese.' A percepção da corte piemontesa sobre Maistre só degenerou após a Revolução Francesa, basicamente por dois motivos: por seu envolvimento na maçonaria, até 1791; por suas ousadas opiniões a respeito da corrupção das primeiras ordens do reino da França, o que era interpretado em Turim como uma crítica indireta à administração piemontesa. Neste interim, as Considerações não só eram 
MAISTRE, Joseph de. Considérations sur la France (1797). In: OC, Vol.I, p.18. mais enfáticas na crítica ao Antigo Regime, como avançavam um paradoxal reconhecimento ao jacobinismo:

0 rei nunca teve aliados, e o fato de que a coalizão atentava contra a integridade da França, constitui algo tão evidente que não representa nenhuma imprudência enunciá-lo. Ora, como resistir à coalizão? Por via de qual meio sobrenatural quebrar o esforço da Europa conjurada? Somente o gênio infernal de Robespierre podia realizar esse prodígio... Todas as vidas, as riquezas, os poderes estiveram nas mãos do poder revolucionário; e esse monstro de força, ébrio de sangue e sucesso, fenômeno espantoso, jamais visto e que nunca mais se verá, foi ao mesmo tempo um castigo horrivel imposto aos franceses, e o único modo de salvar a França... ${ }^{24}$

Poucos estudiosos perceberam que as Considerações articulam e/ ou equilibram o pensamento do contra-revolucionário europeu com o do patriota piemontês/saboiano, sentimentos que caminharão quase sempre paralelos na futura carreira diplomática de Maistre (1803-1817).

Leia-se, por exemplo, a seguinte fórmula provocativa presente nas Considerações, a qual opõe as identidades factuais italiana, francesa, russa e persa à entidade imaginária dos filósofos e revolucionários ('homem'): "A Constituição de 1795, assim como suas antecessoras, foi feita para 0 homem. Mas não existe no mundo nada que se possa chamar de homem. Ao longo de minha vida, tenho visto franceses, italianos, russos, etc.; sei também, graças a Montesquieu, que se pode ser persa. Mas, quanto ao homem, afirmo que, em toda minha vida, jamais o encontrei; se ele existe, desconheço-o completamente". ${ }^{25}$

Contudo e levando-se em conta a leitura retrospectiva de suas obras completas, é possível vislumbrar algo mais nesta incomum alusão aos italianos, uma entidade que, por vias distintas, era tão imaginária e não-factual quanto o homem genérico de Tom Paine, um dos alvos preferenciais de sua crítica. A nosso ver, isto era o reflexo do patriotismo piemontês, o qual assumia cada vez mais um aspecto de política defensiva contra a Áustria e sua política expansionista sobre a península itálica, como se lê num outro trecho das Considerações:

\section{0 que reivindicavam os realistas, quando pediam uma contra-revolução tal como eles imaginavam, isto é, feita bruscamente e pela força? Exigiam a conquista da França e, portanto, sua divisão, o amesquinhamento de sua influência e 0 aviltamento de seu rei, ou seja, massacres talvez de três séculos, consequência infalivel de uma semelhante ruptura do equilibrio. ${ }^{26}$}

A perspectiva da rica carreira diplomática maistreana estava influenciada pelo fato dele representar os interesses de um Estado que, apesar de não ser uma grande potência (não detinha grandes territórios nem grandes exércitos), podia ser considerado a 'pedra angular' do equilíbrio político na península italiana e, por extensão, na Europa, devido à sua privilegiada posição geográfica, isto é, um Estado-tampão que evitava o choque entre duas potências, França e Áustria.

A seu juizo, a Casa d'Áustria, símbolo da coligação européia-cristã contra a Revolução, representava um risco maior que a França revolucionária para sua dinastia. Por mais absurdo que isto parecesse à primeira vista, Maistre percebera com acerto que a Casa da Sabóia nada tinha a temer da França, fosse ela republicana ou monárquica. No primeiro caso, o máximo que o reino do Piemonte tinha a perder era sua província da Sabóia (segundo o princípio revolucionário das fronteiras naturais). Na segunda hipótese, 
27

MAISTRE, Joseph de. Lettre au Baron Vignet des Etoles, 15 agosto 1794. In: DARCEL, JeanLouis (org.). De la terreur à la restauration: correspondances inédites. Revue des Études Maistriennes, vol.10, Paris, 1986-1987, p.97.

28

0 golpe de estado de 18 frutidor (4 de setembro de 1797), com o apoio dos militares, anulou o resultado das eleições da primavera (a qual tinha sido amplamente favorável aos moderados e realistas), frustrando as esperanças dos realistas franceses numa Restauração pacífica, pela via eleitoral. Em decorrência do golpe, estabeleceu-se a censura e a cassação dos deputados suspeitos de simpatias ou implicados em manobras monárquicas (como o recém-eleito presidente do Conselho dos Quinhentos, o general Charles Pichegru). a qual julgava mais plausivel (ou seja, após uma provável Restauração), um enfraquecido Luís XVIII seria o primeiro interessado em estabelecer alianças monárquicas, razão pela qual restituiria, sobretudo por razões estratégicas, a Sabóia ao Piemonte. Mas quando se tratava da Áustria, o julgamento de Maistre era severo: amparado em opiniões de diplomatas austriacos, 0 saboiano concluiu que a razão de Estado daquela dinastia previa necessariamente a absorção e extinção do reino do Piemonte, como passo decisivo para o controle político da Itália. E do ponto de vista do direito internacional europeu, isto era tão ilegítimo e despótico quanto a ação revolucionária dos jacobinos, com o agravante de ser um crime perpetrado por um monarca contra o outro.

0 fato de Maistre sustentar estas idéias num momento em que 0 Piemonte vivenciava um sentimento universal de hostilidade antifrancesa (tão bem expresso nas obras de figuras tão distintas como o pró-absolutista Galeani Napioni e o reformista liberal Vittorio Alfieri, autor do célebre // Misogallo), demonstra o quão heterodoxa era a sua perspectiva contra-revolucionária.

Já em 1794 Maistre confidenciava a um de seus amigos o receio de que a contra-revolução, sob o pretexto de esmagar a revolução na França, provocasse um desequilíbrio ainda maior no cenário político europeu: "É para a pobre Casa da Áustria que queremos entregar a Alsácia, a Lorena e Flandres. Por Deus, que equilíbrio! É do interesse de todos que o imperador nunca adentre na França como conquistador... Não precisamos de um Carlos V"27.

Apesar da notável correção da análise, as desventuras do súdito saboiano do rei piemontês junto a seu Estado aumentaram ainda mais em 28 de outubro de 1797, quando as tropas francesas na Itália, sob o comando de Napoleão, interceptaram em Milão uma carta do favorito de Luís XVIII, o conde d'Avaray, na qual informava que os eventos do frutidor ${ }^{28}$ tornavam impossivel uma nova edição das Considerações em solo francês. Enviada a Paris, a carta foi publicada nos órgãos de imprensa do Diretório para ilustrar a existência de complôs realistas subterrâneos e justificar o golpe de estado.

Desvendada a autoria do virulento panfleto contra-revolcionário, a ascensão política de Maistre passou a ser politicamente inviável a seu governo, uma vez que isto equivaleria a uma declaração de guerra contra o Diretório, com quem o mesmo acabara de assinar um tratado, em maio de 1796.

Era preciso que a Revolução Francesa exercesse um efeito 'libertador' para Maistre, invertendo sua fortuna. E foi o que aconteceu quando Napoleão, em junho de 1798, invadiu e conquistou o Piemonte, forçando o rei da Casa da Sabóia, então aliado da Áustria, a se exilar. Com a ocupação francesa do Piemonte e a fuga do rei Carlo Emanuele IV em dezembro do mesmo ano, Maistre atravessa com sua família o vale do Pó para ganhar Veneza, onde passaria os próximos sete meses.

No final de julho de 1799, tropas austro-russas derrotam os franceses em Turim, permitindo à família de Maistre deixar Veneza, em 26 de agosto. Posteriormente, em 19 de setembro, o autor das Considerações é informado por seu governo que fora nomeado ao cargo de regente da ilha da Sardenha, com um salário de 20.000 libras anuais, enquanto a Áustria impedia que Carlo Emanuele IV retornasse à sua antiga capital.

Entretanto, após a solapadora vitória de Napoleão frente aos austríacos na batalha de Marengo (1800) e a nova invasão francesa sobre a Itália e o Piemonte (dez. 1800), o soberano da Casa da Sabóia teve de se refugiar na ilha da Sardenha. 
Entenda-se por 'pais' a região do Piemonte, a qual fora anexada à França pelas tropas de Napoleão.
É neste momento que a Revolução Francesa, a qual, como ele próprio dissera, já o havia 'libertado' da solapadora insignificância burocrática na Sabóia em 1792, Ihe oferece uma segunda oportunidade para servir não só a seu soberano, mas também à soberana das soberanas, a opinião pública.

Antes mesmo da chegada de Maistre à capital do império russo, o antecessor de Alexandre I, o czar Paulo I, já havia mostrado no Congresso de Rastadt (1797) uma firme disposição em defender o soberano da Casa da Sabóia contra as pretensões da República Francesa e da Áustria. Esta iniciativa isolada rendeu frutos em 1799, com a vitória dos cossacos russos comandados pelo general Souvarov (o qual seria evocado por Stálin nos momentos derradeiros da invasão nazista à Rússia) sobre as tropas de ocupação francesa, devolvendo o Piemonte, a Lombardia, Roma, os ducados de Parma, Toscana, Modena e o reino de Nápoles (em cujos territórios foi instituída a efêmera República Partenopea, que durou menos de um ano, em 1799) a seus antigos soberanos (na ordem), os rei sardo, a Áustria, o papa, os duques da casa de Lorena (um ramo da Casa da Áustria) e os Bourbons.

Mais do que nunca, o rei sardo (reduzido à Sardenha entre 1800 e 1814) dependia do apoio diplomático e dos subsídios ingleses e russos para subsistir. Por uma ironia do destino, coube àquele que a corte piemontesa suspeitava de filojacobinismo e desdenhava como 'll Francese' a execução de parte deste plano vital às pretensões da dinastia. Isto porque o decreto de 10 messidor (29 de junho de 1802) obrigava todos os piemonteses ausentes a retornar imediatamente a seu novo 'país' 29 , sob pena de confisco das propriedades. Diante disto e das insistentes reclamações do Regente Charles-Félix (irmão de Vittorio Emanuele), contra Maistre (pois este opunha inúmeras barreiras legais às medidas extra-judiciais daquele, como a proibição da tortura e concessão de habeas corpus a presos políticos sem provas), bem como do retorno forçado do piemontês conde de Vallaise da embaixada sarda de São Petersburgo e da redução aguda dos quadros após o decreto napoleônico, não restou ao despossuído e 'abandonado' soberano da Casa da Sabóia senão nomear o súdito saboiano mais bem preparado para aquela missão. E assim, em 23 de outubro de 1802, Maistre recebe a investidura do cargo de "Envoyé extraordinaire" (embaixador) da monarquia sarda na corte do czar, em São Petersburgo.

As perspectivas para o novo diplomata sardo não eram as melhores naquela importante corte européia. Coube a Maistre a dupla missão de mendigar por mais subsídios e de assegurar a proteção de seu reduzido e (praticamente) proscrito Estado pelo czar. Para o exercício desta função, receberia 20.000 libras anuais, o mesmo que recebera como vice-regente da Sardenha, com a diferença de que o padrão de vida em São Petersburgo era incomparavelmente mais alto. Por razões de decoro público e privado, viu-se impossibilitado, diante dos parcos salários, de levar consigo a família, que permaneceu em Turim. Este não seria o único desgaste em relação a seu governo. Além de suas origens saboianas, do passado maçônico e das suspeitas de francofilia, o ardor e a eloqüência do embaixador inquietavam e aborreciam as autoridades sardas.

Com uma notável consciência dos prós e contras de sua personalidade, o embaixador da Sardenha sabia que a única avenida aberta para um pobre representante de uma monarquia impotente era ganhar a confiança e a amizade de pessoas influentes do círculo diplomático russo e, se possivel, do próprio czar. Afinal, a expectativa de reaver seus bens espoliados passava pela restauração dos Bourbons na França, a qual dependia da 


\section{0}

Em 1816, como reação às atividades missionárias dos jesuitas (e também de Maistre) na Rússia, publicou Considérations sur la doctrine et l'esprit de l'Eglise orthodoxe, na qual defendia, num tom nacionalista, a igreja ortodoxa contra as "impurezas heterodoxas trazidas pelos estrangeiros" (LEBRUN, Richard. Op. Cit., p.315).

31

Ibidem, p.183. Isaiah Berlin demonstrou que na obra-prima de Tolstói, Guerra e Paz (1865-8), existem profundos ecos do pensamento de Maistre (o qual chega a ser citado no volume IV, parte III, cap. 19, da obra). Para o filósofo liberal, Maistre e Tolstói estavam "unidos pela incapacidade de escapar do mesmo paradoxo trágico: eram ambos por natureza raposas de olhar perspicaz, inevitavelmente conscientes das simples diferenças de facto que dividem e das forças que desintegram o mundo humano, observadores totalmente imunes aos enganos de muitos estratagemas sutis, de sistemas, credos, e ciências unificadoras, pelos quais os superficiais ou os desesperados procuravam ocultar o caos de si mesmos e dos outros". BERLIN, I. 0 ouriço e a raposa. In: HARTIG, H. e HAWSHEER, R. (orgs.). Estudos sobre a humanidade: uma antologia de ensaios (1997). Trad. de Rosaura Eichenberg. São Paulo: Cia das Letras, 2002. p.447-505.

32

MAISTRE, Joseph de. Mémoire a S.M. le Roi de Sardaigne, 15/12/1812. In: OC, Vol.XII, p.321-322. coalizão antifrancesa formada por Áustria, Inglaterra e Rússia. Inevitavelmente, a Rússia e o czar Alexandre I eram os principais candidatos para o projeto de salvação do reino do Piemonte-Sardenha.

Decidido, portanto, a fazer o melhor uso possível de seu "capital", qual seja, sua brilhante conversação, inteligência, memória e uma reputação de porta-voz do conservadorismo, não demorou muito para que Maistre ganhasse destaque na corte do czar. Um dos principais expoentes daquela corte russa, o conde Alexander Stourdza, que futuramente se oporia ao proselitismo católico do embaixador sardo em solo russo ${ }^{30}$, assim se referiu a Maistre:

Ainda posso ver diante de mim aquele nobre e velho homem, a caminhar sempre de cabeça erguida e coroada por um cabelo esbranquiçado graças à natureza e ao capricho da moda. Sua grande fronte, sua face pálida marcada por figuras tão impressionantes quanto seus pensamentos, também marcados pelas desventuras de sua vida, seus olhos azuis meio turvos pelos profundos e laboriosos estudos e, finalmente, a rematada elegância de seu vestuário, a urbanidade de sua linguagem e de suas maneiras... 0 sr. de Maistre foi, sem sombra de dúvidas, a mais destacada personagem do tempo e do lugar em que vivemos, a saber, a corte do Imperador Alexandre e o período entre 1807 e 1820 ... Éramos todos ouvidos quando, sentado em sua poltrona, de cabeça erguida... o conde de Maistre abandonava-se ao límpido curso de sua eloqüência, gargalhando, argumentando com graça, animando e governando a conversação. ${ }^{31}$

No auge de sua influência política junto ao czar, isto é, em dezembro de 1812, portanto logo após a 'vitória' napoleônica na sangrenta Batalha de Borodino (set. 1812), Maistre, testemunha privilegiada dos eventos (afinal, seu único filho homem, Rodolphe, esteve no campo de batalha ao lado dos russos, o que não foi de pouca relevância política para o rei sardo...) e, portanto, consciente de que aquela batalha era um prelúdio da Restauração, endereça uma memória diplomática ao soberano da Casa da Sabóia, na qual sugere, dentre outras coisas, que seu soberano estabeleça uma política de aliança declarada com os Bourbons franceses e o rei da Prússia, pois, do contrário, a Áustria, a partir da Lombardia, absorveria o Piemonte. Vale a pena reproduzir a linha de raciocínio de Maistre:

Felicitou-se amiúde a Casa da Sabóia por sua feliz posição entre duas potências de primeira ordem cuja desconfiança mútua servia de proteção, mas os inconvenientes desta situação não foram expostos.

Em primeiro lugar..., lançando-se alternadamente de um lado para o outro, segundo seu interesse imediato, [a Casa da Sabóia] declarava assim a seus dois vizinhos poderosos que ela não tinha preferência por nenhum deles, o que, por um justo retorno, fazia com que nenhum deles tivesse uma preferência real por ela. Cada um queria defendê-la do outro, mas sem se inquietar com ela e suas glórias, de modo que valeria perguntar se os seus interesses não seriam melhor defendidos no caso dela se aliar exclusivamente a uma dessas potências... Em segundo lugar, poderia existir mais aparência do que realidade nesta pretensa alternância de posição...; pois nada é mais duvidoso do que a vantagem que resultaria disso, ao passo que 0 inconveniente produzido por ela é visível e incontestável. ${ }^{32}$

Diante da cada vez mais iminente queda de Napoleão e de um futuro congresso europeu, Maistre sugere ao soberano da Casa da Sabóia que o mesmo não medisse esforços para restaurar o status quo anterior à Revolução (isto é, de 1792), tomando o máximo de cautela para evitar 
MAISTRE, Joseph de. Mémoire à consulter sur l'état présent de l'Europe, 12 de outubro de 1806 In: OC, Vol.X, p.468. que a França e, sobretudo, a Áustria, tocassem seus territórios. Feita esta ressalva, lança a seguinte pergunta retórica: qual seria a melhor estratégia diplomática para lograr este objetivo?

A resposta não deixa de surpreender os estudiosos de hoje, quanto mais o soberano e sua corte - os mais prejudicados pelas conquistas da Revolução Francesa (do período republicano ao napoleônico) -, pela ousadia da proposta a, saber, a Casa da Sabóia tinha mais a temer da Áustria do que da França, cujo interesse limitar-se-ia no máximo a Nice e à Sabóia. Curiosamente, a opinião de Maistre era reforçada pela teoria revolucionária jacobina das 'fronteiras naturais', a qual deslocava a ambição territorial francesa da península itálica para as fronteiras orientais do Reno: deste modo, o Piemonte, eterna ambição de Viena, não entraria nos desígnios dos futuros governos da França, quaisquer que fossem os mesmos.

Ademais, o rei Vitório Emanuele I deveria esquecer as justas mágoas e apoiar o restaurado Luís XVIII (mais do que nunca pressionado a agir segundo os parâmetros da legitimidade) nas futuras discussões européias, evitando que as compensações territoriais e financeiras dos coligados fossem gravosas à França e ressuscitassem o sentimento patriótico-nacionalista latente dos franceses: não havia salvação para a Europa ou equilibrio europeu senão pela França. ${ }^{33} \mathrm{Com}$ a Áustria, dava-se o oposto: num futuro congresso europeu, a mesma poderia legitimamente reclamar a Lombardia, a Toscana e Veneza. Ou seja, suas pretensões sobre a Itália setentrional seriam reforçadas após a Restauração, ao contrário da França.

Portanto, para não ser sufocada entre as duas potências (Áustria e França), a Casa da Sabóia deveria instaurar uma abertura diplomática com a França, cujos interesses naturais estavam voltados para as fronteiras do Reno. Por sua vez, seja pela raison d'Etat ou pela natureza das coisas, a Casa d'Áustria era levada irremediavelmente a avançar sobre a Itália setentrional, principalmente sobre a Casa da Sabóia.

As preocupações de Maistre foram endossadas pelo comentário feito por um diplomata austríaco durante as conferências de Lunéville (1801), que selaram um tratado entre a França e a Áustria: "E qual a necessidade de que haja um rei da Sardenha?" ${ }^{34}$

Diante disso, coube ao contra-revolucionário saboiano levar adiante esta delicada missão política, mostrando, através de contatos pessoais ou por meio de inúmeras cartas e mementos diplomáticos (seja ao czar em pessoa, ou ainda ao rei sardo, a Luís XVIII e seu correspondente na Rússia, o conde de Blacas), que a Restauração do reino do Piemonte era do maior interesse para o restabelecimento do equilibrio europeu, especialmente para a França a Rússia e a Prússia (do contrário, a Casa da Áustria teria caminho livre para concentrar suas forças na expansão a oeste do Reno e a leste do Elba).

Neste contexto, uma das maiores proezas diplomáticas de Maistre consistiu em convencer o czar Alexandre I de que era do interesse do império russo a Restauração do reino do Piemonte-Sardenha, pois ambas as dinastias precisavam conter o avanço da Áustria.

Assim, se num dos memorandos diplomáticos que endereça ao czar, Maistre se mostra preocupado com o futuro da 'Itália' pós-napoleônica, veremos que esta preocupação refletia mais uma preocupação de conservação e restauração do poder de sua dinastia (assim como das demais soberanias da península itálica, à exceção da Áustria), do que um sentimento protonacionalista italiano. Ou seja, 'a liberdade da Itália' confundia-se aqui com a Restauração plena e ampliada do reino do Piemonte e o enfraquecimento da Áustria. 
MAISTRE, Joseph de. Mémoire à S.M. I'Empereur de toutes les Russies, 20/03/1813. In: OC, vol.XII, p.351. Rossi, 18 de agosto de 1810. In: OC, Vol.XI, p.218.

38

Ibidem, setembro de 1806, Vol.X, p.203.

39

MAISTRE, Joseph de. Mémoire à son excellence M. de Novosiltzof, 1805. OC, Vol.IX,p.405.

40

Idem. Mémoire à consulter sur l'état présent de I'Europe, janeiro de 1804. OC, Vol.IX, p.131.
Naquela conjuntura de recuos de Napoleão na Rússia, Polônia e Alemanha, Maistre receia que a 'Itália' fosse usada como moeda de troca entre as potências européias num futuro congresso e, sobretudo, que as solicitações de reintegração de domínios continentais do reino da Sardenha fossem ignoradas devido às pressões austríacas, razão pela qual argumenta em defesa da Casa da Sabóia para o czar, esforçando-se em demonstrar que a defesa daquela longínqua dinastia na Península Itálica iria ao encontro de seus interesses: "Não se pode esquecer que S.M.I. confina com o rei da Sardenha, pois... a Áustria toca de um lado a Rússia e, d'outro, o Piemonte, de modo que a Rússia e o Piemonte se tocam. 0 rei da Sardenha... é uma mão com a qual..." [o czar] "pode agir sobre o Pó como sobre a Duma"35.

Após demonstrar brevemente ao czar a (improvável) convergência de interesses do seu império com o reino da Sardenha, Maistre busca legitimar junto ao influente soberano russo uma provável anexação de Gênova ao reino do Piemonte restaurado, pelas seguintes razões: 1. A secular República de Gênova, assim como as outras repúblicas italianas (Veneza e Luca), não mais conseguiria se reorganizar como unidade política autônoma depois que Napoleão quebrou a 'delicada máquina' do 'relógio' republicano (oligárquico); 2. Não lhe restando outra possibilidade de existência política autônoma, era uma questão de tempo a anexação da mesma a uma monarquia, fosse francesa, austríaca ou, como defendia Maistre, piemontesa; 3. Seria do maior interesse da Itália e de todo o equilibrio Europeu que a importante cidade portuária fosse integrada ao reino vizinho do Piemonte, com a dupla vantagem de fechar definitivamente a Itália para a França pelo mar e fortalecer a Casa da Sabóia em detrimento de Viena. ${ }^{36}$

Portanto, é bem no espírito desse conceito de 'equilibrio de poder' (um produto do Tratado de Vestfália, que substituiu a hegemonia do Sacro Império pelo reconhecimento de Estados soberanos e independentes), o qual herdara da leitura de autores como Charles Davenant, David Hume e Fénelon (os quais, diante das pretensões de Luís XIV, também formularam teorias sobre o equilibrio de poder), que o embaixador sardo na corte do czar aconselharia as potências a restaurar os domínios italianos da Casa da Sabóia, bem como a deixar claro ao povo francês que lutavam contra o tirano da Europa (Napoleão) e não contra a nação francesa, a qual não teria nada a temer futuramente com a queda de seu imperador: "0 problema político reduz-se a um só: persuadir os franceses de que a guerra é só contra Bonaparte, e de que nunca terão paz com ele" ${ }^{\prime 37}$.

A seu ver, uma grande calamidade adviria no caso das potências coligadas levarem em conta apenas seus interesses particulares: este fato esteve na raiz da fraqueza das monarquias ante a França revolucionária; perpetuava a força de Napoleão, cujo mérito consistia em dividir para governar. Maistre acusava os soberanos europeus de não serem realistas na acepção do termo: movidos pelo próprio interesse, estabeleceram acordos particulares com quem atacava outras soberanias e feriam na raiz o princípio da legitimidade monárquica na Europa ${ }^{38}$ - razão pela qual jamais hesitou em considerar o poder exercido por Napoleão sobre o continente europeu como 'revolucionário'.39 $\mathrm{E}$ foi justamente para defender uma coalizão com 'perspectivas mais sábias, amplas e européias" 40 que Maistre avançou uma teoria em defesa da conservação dos Estados e soberanias de médio-porte, como o reino do Piemonte-Sardenha, pelo insubstituivel papel que teriam a desempenhar no restabelecimento do equilibrio europeu. 
41

Apesar de concordar com as conclusões absolutistas de Hobbes, Maistre foi um critico contumaz de suas premissas contratualistas, uma vez que para ele semelhante hipótese de 'estado natural' era uma suposição arbitrária (uma hipótese não amparada na experiência ou na história), cujo potencial revolucionário fora demonstrado pela filosofia lluminista do século XVIII (sobretudo através de Rousseau) e pela Revolução Francesa.

42

MAISTRE, Joseph de. Mémoire a S.M. le Roi de Sardaigne, 15/12/1812. In: OC, Vol.XII, p.410.

43

MAISTRE, Joseph de, apud DARCEL, Jean-Louis. De la terreur à la restauration: correspondances inédites..., Op. Cit., p. 97.

44

MAISTRE, Joseph de. Mémoire a S.M. le Roi de Sardaigne, 15/12/1812. In: OC XII: 411.
Isto porque, apesar de sua formação jurídica, Maistre duvidava do potencial persuasório dos acordos diplomáticos legais para arbitrar as relações entre os Estados. Em total acordo com os princípios do ativista contra-revolucionário de 1793-97, a ênfase do futuro embaixador sardo recairia sobre critérios egoísticos de autopreservação e interesse ao invés de princípios universais e/ou abstratos relacionados com o direito internacional ou a moral. À diferença de Hugo Grotius, Maistre não acreditava que a formalidade dos contratos internacionais fosse capaz de garantir a paz per se. Antes, a exemplo de Hobbes, julgava que no plano internacional os Estados se comportavam como indivíduos egoístas, como se os mesmos ainda estivessem numa espécie de 'estado natural't1 (isto é, suas ações são mais passionais e impulsivas do que racionais; eram não apenas insociáveis, mas também violentos), de modo que a justiça seria definida pela raison d'état de cada um.

Para que os Estados lograssem um consenso sobre um determinado conjunto de leis, um considerável número de características comuns deveria ser alcançado, o que estava longe de ocorrer. Como representante de um Estado de médio-porte (sob os aspectos demográfico, territorial e militar), Maistre receava que as intenções cosmopolitas (fossem do Sacro Império, fossem da França republicana ou Imperial) encobrissem projetos de dominação da França e da Áustria sobre a Europa: na esfera das relações internacionais, a experiência demonstrava, os princípios abstratos nada podiam diante dos interesses e das ambições.

Mas, à diferença da perspectiva hobbesiana - a qual sustentava que os Estados menos poderosos não poderiam se manter -, a maistreana enxergava outra vantagem, que não apenas a manutenção do equilibrio de poder, na preservação dos Estados de pequeno e médio porte: a preservação da diversidade cultural no interior do sistema estatal europeu, diversidade esta que deveria florescer para o bem de todos e da civilização (pois os incrementos nas técnicas medicinais e gastronômicas, por exemplo, dependem da existência de Estados particulares, para só depois serem compartilhados e absorvidos por outras culturas: neste caso, um império traria o risco - Maistre não diz, mas avança o conceito - de pasteurização cultural).

Apesar do tamanho e do potencial militar reduzidos, os pequenos e médios Estados tinham um impacto importante no equilibrio de poder, pois constituiam zonas neutras entre duas potências rivais, evitando que as mesmas entrassem em permanente choque. ${ }^{42}$ Ademais, se fosse verdadeiro 0 princípio (muito debatido como uma das causas das fraquezas monárquicas diante da Revolução) de que só deveriam existir grandes potências, os Estados seriam levados inevitavelmente a adotar um modus operandi beligerante de expansão e domínio perpétuos. 0 resultado final disto seria uma escalada inaudita na guerra e no derramamento de sangue: "A sociedade de nações, similar à dos indivíduos, é composta de grandes e pequenos exemplares, onde a desigualdade é algo necessário"43. 0 princípio de que "só deveriam existir grandes potências" deveria ser substituído por outro, a saber, que "nenhuma nação está destinada pela natureza a estar submetida a uma outra"44.

Quando o prestígio de Maistre na corte russa e junto ao czar havia alcançado o seu zênite (no final de 1811, foi investido para a função de redator de todos os documentos públicos e privados do czar), a invasão francesa de 1812 estragou suas pretensões (de representar diretamente as dinastias sarda e russa no futuro Congresso de Viena), ao provocar um recrudescimento do sentimento nacional russo, representado numa atitude profundamente hostil e xenofóbica a tudo que remetesse ao ocidente, inclusive os jesuitas, que terminaram sendo expulsos do império, em 1816. 
Maistre, que pensara em se estabelecer na Rússia com a chegada de sua família às vésperas do natal de 1814, viu-se obrigado a abandonar os domínios do czar quando soube que Alexandre I exigira seu retorno a Turim, em abril de 1816. 0 saboiano, assim como os jesuítas, pagava o preço pela bem-sucedida atividade missionária desempenhada na corte russa, convertendo figuras eminentes como a condessa de Rostopchin (esposa do governador de Moscou), a condessa Tolstoy (esposa do mestre-de-cerimônias da corte), a condessa Golovine (dona de um freqüentado salão) e Mme Sophie Swetchine (que se tornaria uma figura influente nos círculos intelectuais católicos franceses do século XIX).

Do seu retorno a Turim, em 1817, a seu falecimento, em 26 de fevereiro de 1821, dedicaria a maior parte de sua energia às publicações de $D u$ Pape (1819) e das Soirées de Saint-Pétersbourg (1821), obras que consolidaram sua reputação de contra-revolucionário teocrata e ultramontano.

Somente em dezembro de 1818 teve a situação definida ao ser nomeado como ministro de estado e "Régent de la Grande Chancellerie" (acumulando as funções de vice-chanceler e de Ministro da Justiça) do restaurado reino do Piemonte-Sardenha. Apesar do desapontamento gerado pela nomeação - Maistre esperava por algo mais, como a embaixada da Casa da Sabóia em Roma -, cumpriu seriamente suas responsabilidades, as quais se prolongaram até 24 de julho de 1820, quando uma repentina crise de saúde condenou-o a ficar paralisado em casa até o fim de seus dias. Além do mais, o quase setuagenário saboiano poderia gozar do merecido descanso da política, uma vez que a Casa da Sabóia teve todos os seus domínios restaurados (Sabóia, Nice e Piemonte), com o fundamental acréscimo da Ligúria.

Longe de descansar, o saboiano ainda encontrou forças para combater o espírito (que julgava mais vivo do que nunca) da Revolução Francesa (através de obras como Du pape, De l'Eglise gallicane e Soirées de Saint-Pétersbourg) e, no outono de 1820, fazer oposição a um apelo constitucional (inspirado nas Cortes espanholas) movido pelos nobres oficiais do exército, os quais também queriam que o Piemonte liderasse a guerra de liberação da Itália.

Os ministros piemonteses mostraram-se favoráveis a uma reforma amparada tanto na Carta francesa de 1814 , como na espanhola para, logo em seguida, liderar a Itália numa guerra de libertação contra a Áustria. Maistre então remou na contramão do que pretendia a maior parte da aristocracia do reino do Piemonte-Sardenha - a qual, contando com figuras como a de Cesare Balbo, conciliava e/ou equilibrava sentimentos de fidelidade dinástica com desígnios de unificação nacional -, sugerindo que aquelas propostas ('apesar de úteis e boas em si') não deveriam ser levadas adiante tendo em vista as circunstâncias: "A terra sob seus pés treme

MAISTRE, Joseph de. Notice Biographique. In: OC, Vol.I, p.XLI. e vocês ainda pensam em construir!"45. Importa dizer que a sua proposta foi a que prevaleceu junto a Vittorio Emanuele I (o qual, em 1821, preferiu abdicar a fazer concessões liberais aos revoltosos).

Somente em 1848, na atmosfera da Primavera dos Povos (fevereiro de 1848) é que o grupo de nobres liberais-reformistas piemonteses, responsáveis pela malograda e efêmera conspiração liberal do Piemonte (1821), conseguiram obter do rei Carlo Alberto o Statuto Albertino, ainda inspirado na Constituição orleanista de 1830 e belga de 1831.

Quis o destino que a Itália ocupasse os últimos pensamentos de Maistre. Na mesma carta citada acima, o autor de Du Pape (1819) fez as seguintes reflexões: 
MAISTRE, Joseph de. Lettre A M. le Marquis D'Azeglio, 21/02/1821. OC, Vol.XIV, p.257.

47 Idem. Du Pape (1819). In: OC, Vol.II, p.237-247.

48

SALVEMINI, Gaetano. Scritti di storia moderna e contemporanea (1961). Milano: Feltrinelli, 1973. p.524.
Recebido para publicação em fevereiro de 2012 Aprovado em março de 2012
Como vós, por mais de mil vezes meditei sobre esta bela Itália, sem chegar a uma conclusão. Certamente, a grande desgraça para uma nação é ter de obedecer a uma outra... 0 homem sábio... não sabe ao certo no que pensar quando alguém menciona o espírito italiano..., mas logo retorna a si mesmo e se mantém em repouso após observar as terriveis catástrofes que teria de passar para ressuscitar a Itália. Ela paga caro pela terrivel unidade que outrora esmagava o mundo... Hoje, por sua vez, o anátema que a esmaga é o da divisão, cujo fim não se pode imaginar. ${ }^{46}$

Maistre não diz aqui como remediá-la (a divisão italiana), mas em Du Pape (1819) expôs com clareza sua posição a este respeito. Neo-guelfo, via o papa não apenas como um protetor do catolicismo (ou melhor, da religião, da monarquia e da sociedade civil tout court), mas também como um "líder natural da associação italiana"(o qual presidiria, por assim dizer, um conseIho ou confederação de soberanos italianos). Não por acaso, o sentimento anti-austríaco de Maistre deita raizes profundas na política josefista do século XVIII (cuja versão francesa fora o galicanismo/jansenismo), responsável, dentre outras coisas, pela expulsão e supressão da ordem jesuítica em quase toda a Europa (para ele, um dos pré-requisitos da Revolução). ${ }^{47}$

Conclui-se que esta carta denota claramente o caráter defensivo de um gentil-homem relutante em substituir os critérios identitários consolidados no Antigo Regime por outro (rebento da era da revolução democrática): na ausência de algo mais preciso, considerava-se tão somente um cristão saboiano e súdito da Casa da Sabóia, não um 'italiano', identidade esta típica da era da revolução democrática e a qual, antes de nascer, teria de subsumir todas as demais.

Curiosamente, a publicação (em 1858) de sua correspondência diplomática foi patrocinada por ninguém menos do que o conde Cavour (1810-1861), cuja ascensão política foi pautada por um duplo combate intestino no Piemonte: contra o influente partido neo-guelfo piemontês (de Vincenzo Gioberti e Massimo d'Azeglio) e contra os nacionalistas conservadores (municipalistas exclusivistas e pró-austríacos), encabeçados por Solaro della Margarita.

Portanto, se por um lado é verdade que, conforme demonstrou o historiador Gaetano Salvemini em seu estudo sobre o Risorgimento, "... jamais em sã consciência os soberanos saboianos ou seus funcionários contaram com este resultado distante [isto é, a unificação]"48, por outro, levando-se em conta a estrutura sócio-política da península, como ignorar que aquele era o caminho mais viável, razão pela qual, na visão do mesmo Salvemini, trata-se de algo ocioso considerar o processo de unificação italiana (liderada pela monarquia piemontesa e, em menor grau, pelas elites da classe-média) como uma 'Revolução traída'? Ademais, como ignorar o forte impacto exercido indiretamente por Maistre neste processo, ele que, na condição de embaixador da Casa da Sabóia (entre 1803-1817) na corte russa, foi o principal responsável não só por recolher os subsídios que sustentaram diretamente o rei sardo e sua despossuida corte durante todo o periodo napoleônico, como, sobretudo, por convencer pessoalmente o czar Alexandre I, bem como o futuro rei francês Luis XVIII, da necessidade da restauração plena do reino do Piemonte-Sardenha (do contrário, a Áustria concentraria seus esforços na expansão a oeste do Reno e a leste do Elba)? Uma contribuição não-intencional e possivelmente à revelia, mas certamente eficaz (e, paradoxalmente, movida por paixões e interesses contra-revolucionários não necessariamente anti-franceses)... 